\title{
20042 点吊り振子の 3 つの mode 間非線形相互作用の解析と線形振動実験 An Analysis of Nonlinear Mode Coupling in Three Modes of Bifilar Suspension Pendulum and Experiments of Linear Oscillations
}

\author{
○正 舟田 敏雄 (沼津高專), 学 木八内 智貴 (沼津高専), 学 桜井 賢人 (沼津高専), 正 宮内 太積 (沼津高專), 望月 孔二 (沼津高専),
} 正 大庭 勝久 (沼津高専), 青木 悠祐 (沼津高専)

Toshio FUNADA, Toshiki KINOUCHI, Kento SAKURAI, Tatsumi MIYAUCHI, Kouji MOCHIZUKI, Katsuhisa OHBA, Yusuke AOKI Numazu National College of Technology, Ooka 3600, Numazu, Shizuoka, 410-8501

\begin{abstract}
A bifilar suspension pendulum, a uniform density bar suspended at its two points by two strings of same length, may swing in a vertical plane or make torsional oscillation about a vertical axis. The swinging in a co-plane of the strings and the bar is called Mode 1, and the swinging in a vertical plane perpendicular to the bar is Mode 2. Mode 3 is the torsional oscillation about a vertical axis. These modes are linearly independent of each other, but it is possible to make nonlinear coupling oscillation between the modes and internal resonance. In order to treat such coupling systematically, the formulation of the problems is made on two spherical coordinates systems and equations of motion for the three modes are derived. Linear oscillations are examined for the three modes based on experiments to solve nonlinear coupling.
\end{abstract}

Keywords: Bifilar Suspension Pendulum, Coupling of Three Oscillation Modes, Internal Resonance

が一致する条件より $c=a, c=b^{2} /(3 a)$ が得られる. 一方, 先の 実験結果 (Fig.2) では $b=0.4495, a=0.26$ なので, $c=a=0.26$ で mode 1,2 の固有角振動数が一致し, $c=b^{2} /(3 a)=0.259039$ で 3 つの mode の固有角振動数が一致することが理論的に示され る. 実験では $c \sim a$ で 3 つの共振点と推定されたが, それは理論 的に確認された. ここでは, 非線形連成振動の解析に向け, 様々 な連成振動の可能性を線形理論に基づき個々に論ずる.

\section{2 点吊り振子の 3 つの振動 mode の球座標系表現}

水平右手方向に $x$ 軸，水平手前方向に $y$ 軸，鉛直下方向に $z$ 軸と するデカルト座標系 $(x, y, z)$ を用い, Fig.3に示すように, $C_{1}$ 点 を起点に 2 点吊り振子の配置を記述する

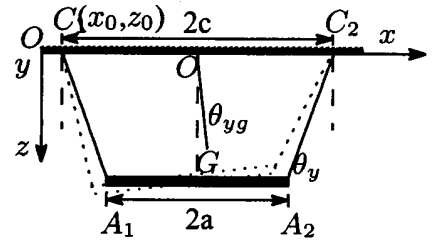

Fig.3 Bifilar suspension pendulum with $c>a$ (mode 1).

球座標系を併用し，座標原点は適宜取るものとする. 水平 な上壁面上に $C_{\mathrm{r}}$ 点 $\left(x_{0}, y_{0}, z_{0}\right)$ を取り, 間隔 $c_{1}$ で, $O$ 点 $\left(x_{0}+c_{1}, y_{0}, z_{0}\right), C_{2}$ 点 $\left(x_{0}+2 c_{1}, y_{0}, z_{0}\right)$ を取る: 遊動円木の 中央 (質量中心) を $G$ 点 $\left(x_{g}, y_{g}, z_{g}\right)$ とし, $G$ 点から間隔 $a_{1}$ で, 遊動円木上の左の紐の結び目位置を $A_{1}$ 点 $\left(x_{1}, y_{1}, z_{1}\right)$, 右の紐 の結び目位置を $A_{2}$ 点 $\left(x_{2}, y_{2}, z_{2}\right)$ と表す. 回転角をデカルト座 標系の軸回りに取って軸名の添え字を付け， $O$ 点を原点とする 球座標系 $\left(r, \theta_{y}, \theta_{z}\right)$ を用い, $z-x$ 面内で鉛直軸から反時計回りに $\theta_{y g}, y-z$ 面内で鉛直軸から反時計回りに $\theta_{x g}$ を取り， $G$ 点の座 標 $\left(x_{g}, y_{g}, z_{g}\right)$ は次式で表される:

$x_{g}=r_{g} \sin \left(\theta_{y g}\right)+x_{0}+c_{1}, y_{g}=r_{g} \cos \left(\theta_{y g}\right) \sin \left(\theta_{x g}\right)+y_{0}$,

$z_{g}=r_{g} \cos \left(\theta_{y g}\right) \cos \left(\theta_{x g}\right)+z_{0}$

また, $G$ 点を原点とする球座標系を用いて, $z-x$ 面内で鉛直軸か ら反時計回りに $\theta_{y}, x-y$ 面内で鉛直軸から反時計回りに $\theta_{z}$ を取 り, $A_{1}$ 点の座標 $\left(x_{1}, y_{1}, z_{1}\right)$ と $A_{2}$ 点の座標 $\left(x_{2}, y_{2}, z_{2}\right)$ は次式 で表される:

$x_{1}=x_{g}-a_{1} \cos \left(\theta_{y}\right) \cos \left(\theta_{z}\right), y_{1}=y_{g}-a_{1} \cos \left(\theta_{y}\right) \sin \left(\theta_{z}\right)$,

$z_{1}=z_{g}+a_{1} \sin \left(\theta_{y}\right)$

$x_{2}=x_{g}+a_{1} \cos \left(\theta_{y}\right) \cos \left(\theta_{z}\right), \quad y_{2}=y_{g}+a_{1} \cos \left(\theta_{y}\right) \sin \left(\theta_{z}\right)$,

$z_{2}=z_{g}-a_{1} \sin \left(\theta_{y}\right)$

Fig.2 Period $T$ versus $c$ for mode 1 (solid line), 2 (dotted), 3

(dashed). $L=0.443$ (below), $L=0.542$ (middle), and $L=0.648$ (above). Marks are $\left(c, T_{e}\right)$ for experimental $T_{e}$.

3 つの mode の線形振動解析により, mode 1,2 の固有角振動数 $\left.L_{1}\right)$ 一定であるとし $\overline{A_{1} A_{2}}=2 a_{1}$ は $f_{0}=0, \overline{A_{1} C_{1}}=L_{1}$ は $f_{1}=0, \overline{A_{2} C_{2}}=L_{2}$ は $f_{2}=0$ で表され る. 水平面からの遊動円木の傾き角の関係式が求められる， $f_{1}$, 
$f_{2}$ の和を取ると, $r_{g}$ を $\theta_{y}, \theta_{z}$ で表現する式が得られる:

$$
\begin{aligned}
f_{1}+f_{2}=0 \rightarrow r_{g} & =\sqrt{L_{1}^{2}-\left(a_{1}^{2}+c_{1}^{2}-2 a_{1} c_{1} \cos \left(\theta_{y}\right) \cos \left(\theta_{z}\right)\right)} \\
& \equiv r_{g 1}\left(\theta_{y}, \theta_{z}\right)
\end{aligned}
$$

$f_{1}, f_{2}$ の差を取ると角度の関係式が得られ， $\theta_{y}$ を個別の振動 mode を記述する変数 $\theta_{x g}, \theta_{y g}, \theta_{z}$ で表現できる:

$$
\begin{aligned}
f_{1}-f_{2} \rightarrow \theta_{y} & =\arcsin \left(d_{11} / c_{11}\right)-\arcsin \left(b_{11} / c_{11}\right) \\
& \equiv \theta_{y 1}\left(\theta_{x g}, \theta_{y g}, \theta_{z}\right)
\end{aligned}
$$

但し， $a_{11}-d_{11}$ は次のように定義した:

$$
\left\{\begin{array}{l}
a_{11}=\cos \left(\theta_{x g}\right) \cos \left(\theta_{y g}\right), \\
b_{11}=-\cos \left(\theta_{z}\right) \sin \left(\theta_{y g}\right)-\cos \left(\theta_{y g}\right) \sin \left(\theta_{x g}\right) \sin \left(\theta_{z}\right), \\
c_{11}=\sqrt{a_{11}^{2}+b_{11}^{2}}, d_{11}=-\frac{c_{1}}{a_{1}} \sin \left(\theta_{y g}\right)
\end{array}\right.
$$

この系の静止平衡状態は，5つの時間の関数を用いて記述され $\tau\left(r_{g}, \theta_{x g}, \theta_{y g}, \theta_{y}, \theta_{z}\right)=\left(r_{g 0}, 0,0,0,0\right)$ と表される. 但し, $r_{g 0}$ は次式で定義される:

$$
r_{g 0}=\sqrt{L_{1}^{2}-\left(a_{1}-c_{1}\right)^{2}}
$$

静止平衡状態の回りで攪乱に対して (2.4), (2.5) 式を Taylor 展開 し, 微小 parameter $\epsilon(\epsilon \ll 1)$ を用いて靦乱を $\epsilon \theta_{y g}, \epsilon \theta_{x g}, \epsilon \theta_{z}$ と 表すと, $\theta_{y}, r_{g}$ は次のように近似される：

$$
\begin{gathered}
\theta_{y} \equiv \theta_{y 1}\left(\theta_{x g}, \theta_{y g}, \theta_{z}\right)=\theta_{y 1}, \\
r_{g}=r_{g 1}\left(\theta_{y 1}\left(\theta_{x g}, \theta_{y g}, \theta_{z}\right), \theta_{z}\right)
\end{gathered}
$$

つまり, (2.9) 式の $\theta_{y}$ には (2.8) 式を代入して項を整理し， $O\left(\epsilon^{4}\right)$ まで取るものとする.

以上の表式を用いて, 質量 $m_{1}$, 慣性 moment $J_{y}, J_{z}\left(=J_{y}=\right.$ $\left.m_{1} b_{1}^{2} / 3\right)$ の遊動円木の運動を記述する Lagrange 関数 $\mathcal{L}$ は，次の ように表される:

$\mathcal{L}=\frac{m_{1}}{2}\left(\dot{x}_{g}^{2}+\dot{y}_{g}^{2}+\dot{z}_{g}^{2}\right)+\frac{J_{y}}{2} \dot{\theta}_{y}^{2}+\frac{J_{z}}{2} \epsilon^{2} \dot{\theta}_{z}^{2}+m_{1} g z_{g}$ ここでは, $C_{1}$ 点の座標が時間の関数となる場合も含まれている. $C_{1}$ 点が固定の場合には， $x_{0}=0, y_{0}=0, z_{0}=0$ である. ここ で, 時間の未知関数は $r_{g}=r_{g 1}\left(\theta_{y 1}\left(\theta_{x g}, \theta_{y g}, \theta_{z}\right), \theta_{z}\right), \theta_{x g}, \theta_{y g}$, $\theta_{y}=\theta_{y 1}\left(\theta_{x g}, \theta_{y g}, \theta_{z}\right), \theta_{z}$ であり, 束縛条件 $f_{1}, f_{2}$ により，運動 を記述する上で基本となる変数 (未知関数) は 3 つである．この 一般関係式に基づき，3つの振動の非線形連成振動系の運動方程

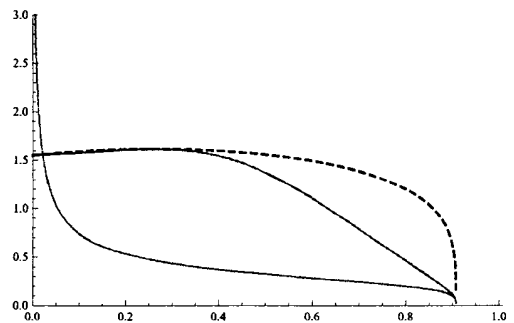

Fig.4a $\{0.648,0.2375,0.26,0.26,0.0866667\}$.

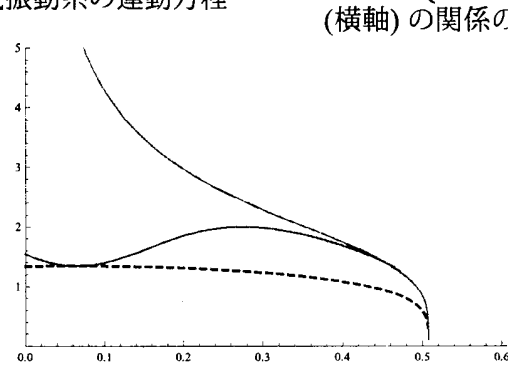

Fig.4b $\{0.443,0.2375,0.065,0.4495,1.0362\}$
式を導出でき，3つの振動の統一的表現が得られる．それに先立 ち, 系の個々の振動 mode の記述との関連を調べる.

遊動円木 mode この振動 mode は $z-x$ 面内で起こるので, 線形化運動方程式の解 $\theta_{y g}(t)$ は調和振動を表し, 固有角振動数 $\omega_{01}$ は次のように表される:

$$
\omega_{01}=\sqrt{\frac{m_{1} g\left(r_{g 0}^{2}+\left(a_{1}-c_{1}\right)^{2} c_{1} / a_{1}\right)}{r_{g 0}\left(\left(1-c_{1} / a_{1}\right)^{2} J_{y}+m_{1} r_{g 0}^{2}\right)}}
$$

ワブランコ mode この振動 mode は $y-z$ 面内で起こるので, 線形化運動方程式の解 $\theta_{x g}(t)$ は調和振動を表し, 固有角振動数 $\omega_{02}$ は次のように表される:

$$
\omega_{02}=\sqrt{g / r_{g 0}}
$$

これより, $c=a$ のとき $r_{g 0}$ が最大値となる

㨭れ振動 mode この振動 mode は $x-z$ 面内で起こり, 線形 化運動方程式の解 $\theta_{z}(t)$ は調和振動を表し, 固有角振動数 $\omega_{03}$ は 次のように表される:

$$
\omega_{03}=\sqrt{m_{1} g a_{1} c_{1} /\left(J_{z} r_{g 0}\right)}
$$

これより, $c=a$ のとき $r_{g 0}$ が最大值となる

口連成振動の条件 $(2.11),(2.12),(2.13)$ 式より， $\omega_{01}^{2}=\omega_{02}^{2}$ は 整理して分母を払うと $c_{1}$ の 3 次代数方程式になり, 根 $c_{1}=a_{1}$ (重根), $c_{1}=b_{1}^{2} /\left(3 a_{1}\right)$ を得る. (2.12), (2.13) 式より, $\omega_{02}^{2}=\omega_{03}^{2}$ は $c_{1}$ の 1 次代数方程式になり, 根 $c_{1}=b_{1}^{2} /\left(3 a_{1}\right)$ を得る. (2.13), (2.11) 式より, $\omega_{03}^{2}=\omega_{01}^{2}$ は $c_{1}$ の 1 次代数方程式になり, 根 $c_{1}=b_{1}^{2} /\left(3 a_{1}\right)$ を得る. 換言すると, $c_{1}=a_{1}$ (並進 2 点吊り振子) の場合には mode 1,2 の固有角振動数が一致し, $c_{1}=b_{1}^{2} /\left(3 a_{1}\right)$ の場合に 3 つの mode の固有角振動数が一致する. さらに, 有利 数 $\alpha_{1}, \alpha_{2}, \alpha_{3}$ を用いて, 次の方程式を作り， $c_{1}$ あるいは $b_{1}$ の代 数方程式として解くことができ， $\alpha_{1}$ の值を変えて高調波/分数調 波の発生を調べることができる:

$$
\omega_{01}^{2}=\alpha_{1}^{2} \omega_{02}^{2}, \omega_{02}^{2}=\alpha_{1}^{2} \omega_{03}^{2} . \omega_{03}^{2}=\alpha_{1}^{2} \omega_{01}^{2}
$$

個別振動解析による実験結果の分析 木片による様々な実 験条件 $\left\{L_{1}, c_{1}, a_{1}, b_{1}, \frac{b_{1}{ }^{2}}{3 a_{1}}\right\}$ の值を伴い, 振動周期 (縦軸) と $c_{1}$ (横軸)の関係の特徴的な例を Fig.4a-4cに示す.

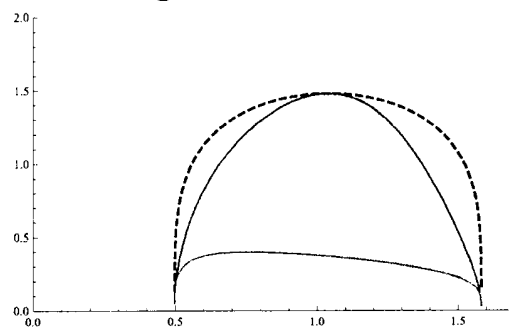

Fig.4c $\{0.542,0.2375,1.04,0.4495,0.06476\}$.
Fig.4a の mode 1 (赤色) と mode 2 (黒色破線) は, 先の実験值 (Fig.2)に比べ, 棒が短くなったため慣性 moment が小さくなり, 周期の值の差が大きくなっている. 従って, mode 1 の周期の倍 が mode 2 の周期となる $c_{1}$ の配置がある．また, mode 3 (赤紫 色) の周期は， $c_{1}$ に対する変化率が大きく，ほかの周期の $1 / 2,1 / 3$ となる $c_{1}$ の配置がある. このような視点で, Fig.4b,4c の振動の 特性を分析できる. 各 mode の振動周期が 2 点吊り振子の設定条 件により大きく変化することに注目されたい，以上の図中で，曲 線の交点は共振点にあたるが, 線形振動では互いに独立であるの で, 交点の近傍で弱非線形の連成振動が起こるものと思われる. また, 各 mode の周期の倍数あるいは分数の曲線で交点が生じ得 る. それらも，非線形連成振動の候補である.

\section{3 おわりに}

本報告では，球座標系を用いた統一的表現に改め，非線形連成振 動等の解析に向けて準備した. 先の線形振動で得られた分散関係 式と関連する表式は，いずれも新たな表現と一致することが確認 された. これに基づき，非線形連成振動等を扱うことになる. 本 報告の結果を基に，主共振，高調波/分数調波の連成振動等につい
て数值解析並びに多重尺度法による解析等に取組む予定である.

\section{参考文献}

[1] 川口 衛, 立道 郁生: “21318 並進振子原理を用いた免震シス テムの開発: その 1 原理と免震床の実大実験” 学術講演梗概 集. B-2, 構造 II, 振動, 原子力プラント 2000 (2000), pp.635636(社団法人日本建築学会)

[2] 望月 孔二, 宮内 太積, 舟田敏雄, 佐々木 隆吾, マズニア ルイルファン, 川船 雄一郎, 川上誠, 中道 義之: “2 点吊 り振子の線形運動解析” 沼津高専研究報告 第 44 号 (2010), pp. $55-60$.

[3] 舟田敏雄, 宮内太積, 大庭勝久, 中道 義之, 青木悠祐, 出川 智啓, 望月 孔二: “2 点吊り振子の連成振動と内部共振の数 值解析” 日本機械学会 2011 年度年次大会, 2011 年 9 月 11 日 (日) 15 日 (木), 東京工業大学 大岡山キャンパス, [OS] $\mathrm{G} 100$ 機械力学 - 計測制御部門 9 月 13 日 (火) 9:00-10:00 会 場 : W242, 講演番号 G100033. 日本機械学会 2011 年度年 次大会 講演論文集 DVDROM G100033.pdf. 